Western University

Scholarship@Western

Department of English Publications

English Department

2012

\title{
From Tawaif to Wife? Making Sense of Bollywood's Courtesan Genre
}

Teresa Hubel

Huron University College, Canada, tdhubel@huron.uwo.ca

Follow this and additional works at: https://ir.lib.uwo.ca/englishpub

Part of the English Language and Literature Commons, Feminist, Gender, and Sexuality Studies Commons, Film and Media Studies Commons, and the South and Southeast Asian Languages and $\underline{\text { Societies Commons }}$

Citation of this paper:

Hubel, Teresa, "From Tawa'if to Wife? Making Sense of Bollywood's Courtesan Genre" (2012). Department of English Publications. 137. https://ir.lib.uwo.ca/englishpub/137 


\title{
C HA P TER 12
}

\section{From Tawa'if to Wife? Makıng Sense of Bollywood's Courtesan Genre}

\author{
Teresa Hubel
}

Although constituting what might be described as only a thimbleful of water in the ocean that is Hindi cinema, the courtesan or tawa' if film is a distinctive Indian genre, one that has no real equivalent in the Western film industry. With Indian and diaspora audiences generally, it has also enjoyed a broad popularity, its music and dance sequences being among the most valued in Hindi film, their specificities often lovingly remembered and reconstructed by fans. Were you, for example, to start singing "Dil Cheez Kya Hai" or "Yeh Kya Hua" especially to a group of north Indians over the age of about 30 , you would not get far before you would no longer be singing alone. ${ }^{1}$ Given its wide appeal, the courtesan film can surely be said to have a cultural, psychological, and ideological

1. "Dil Cheez Kya Hai" is one of the lead songs in Umrao Jaan (directed by Muzzaffar Ali in 1981), while "Yeh Kya Hua" is from Amar Prem (directed by Shakti Samanta in 1971). 
significance that belies the relative smallness of its genre. Its meaning within mass culture surpasses its presence as a subject. ${ }^{2}$

And that meaning, this chapter will argue, is wrapped up not only in the veiled history of the courtesans, a history that Hindi cinema itself has done much to warp and even erase, but in the way in which the courtesan figure camouflages a deep-seated anxiety about female independence from men in its function as a festishized "other" to the dominant female character, the wife or wife-wannabe, whose connotation is so overdetermined in mainstream Indian society that her appearance in Hindi cinema seems mandatory. Is any Hindi film complete without this standard kind of heroine? The sheer universalism of her existence on the screen would seem to make any deviation from her and her devotion to the heterosexual marriage something of a radical alternative when it comes to depictions of the feminine. And herein might lie the pull of the courtesan film: it offers its viewers a break from what can only be called the banality, because it is so commonplace, of the wife and wifeto-be narrative.

Or so it would seem. In fact, the courtesan film too usually relies on this narrative, and this creates something of a conundrum for scholars such as Poonam Arora (1995: 82), who remarks:

It is interesting that even though actual tawa' ifs have lived as extremely wealthy and independent women who invariably shun marriage and prefer lesbian relationships (as Oldenburg has shown), the narratives about them persistently represent them as wanting to escape from their lives into "respectable" heterosexual marriages. ${ }^{3}$

This is certainly true of the courtesan heroines in such films as Pakeezah (directed by Kamal Arohi in 1971), Khilona (directed by Chandar Bohra

2. By "courtesan film," I mean those films in which the courtesan is the protagonist and the focalizer of the narrative, not those many other Hindi films that contain courtesan characters who function only as catalysts of some kind of action that affects the protagonist or as minor characters.

3. Arora is referring here to Veena Talwar Oldenburg's famous anthropological study of a group of courtesans in North India, entitled "Lifestyle as Resistance: The Case of the Courtesans of Lucknow, India." Like Arora, in their book Islamicate Cultures of Bombay Cinema, Ira Bhaskar and Richard Allen comment on the "paradox" at the heart of the courtesan film but do not pursue its implications. They write, "the Courtesan film suggests the honour that is attached to the cultivation of the arts, though, paradoxically, the courtesan herself is a figure around whom these notions of honour cannot be constructed and who must be sacrificed to preserve the honour of the home" (Bhaskar and Allen 2009: 22). in 1970), and Tawaif (directed by B. R. Chopra in 1985), not to mention the latest version of Umrao Jaan (directed by J. P. Dutta in 2006), where Umrao is physically ruined by her yearning for a man she loves but cannot marry, a man who will not have her; the last shot is a close-up of her face so swollen with tears and years and years of grief that the viewer is hard-pressed to recognize that face as belonging to the beauty queen and Bollywood star Aishwarya Rai. This is a shocking moment in the film, one which seems to suggest that Umrao is somehow receiving her just deserts for her failure to secure her man in marriage. Or maybe we are meant to read this horrible and ugly image as the director's metaphor for the wreckage that a courtesan's unmarried life must eventually become.

A classic courtesan film Pakeezah enacts this movement from tawa'if to wife as its primary theme. Its heroine, Shahaabjan (Meena Kumari), who at the start of the film is depicted as a vivacious, playful, and happy young woman, whose singing and dancing in the $k o t h a^{4}$ seem to give her great pleasure, after falling in love with Salim and being unable to marry him because of her profession, famously declares the courtesan to be a living corpse. Shahaabjan is eventually freed from her life as a zombie when she is recognized as the daughter of a respectable, domestic household and consequently becomes an eligible bride for Salim. The sign of her newly acquired respectability is that she stops singing and dancing, even stops smiling, and, with a demure quietness quite at odds with the earlier twirling girl and her tinkling ankle bells, sits modestly in a palanquin tearfully waiting to begin her wedding procession, her head covered by her bridal veil, a sign of her unavailability to the eyes of men other than her husband and his family. As in Khilona and Tawaif, the marriage that is about to take place at the end, though founded on the tragedy of her father's death, is nevertheless meant to be read as a happy ending for the courtesan. But I must admit that in all three cases I remain unconvinced by the logic of these films, each of which initially either portrays the life in the kotha as colorfully vibrant and exciting, or suggests that, for these women, there is a meaningful happiness to be found in the production of art, or represents the tawa if herself as charming and strong, as a woman who is willing to stand up to even dangerous men. Considering these depictions of interesting women leading gratifying lives at the start of

4. Kotha means salon, though it is sometimes translated as brothel. 
their stories and the restrictions on their freedom that marriage tends to imply in these films and others, I find it difficult to interpret the marriages at the end as anything but a step down.

Other scholars have pursued this line of inquiry further than Arora. Pointing out that the inevitable conflict in a courtesan film is the "tension between the tawaif identity and the narrative's need to have her married to the hero" (Arora 1995: 13-14), Gregory D. Booth (2007: 8) argues that these films present a revisioning of the standard role of the heroine. Courtesan heroines are very much unlike "conventionally respectable women characters" in that they tend not to demonstrate the selfsacrificing, suffering passivity that makes these more common female roles admirable to mainstream filmmakers and their audience. Instead, he insists, tawa'ifs behave more like heroes than heroines, dynamically engaging in a quest that is sometimes driven even by a desire for vengeance, though that quest is also conventional in its goal-namely to achieve a normative, monogamous heterosexuality. Acknowledging that tawa 'if-centered narratives are like "no other story-type and like no other Hindi films" (Booth 2007: 20) because they are basically action movies involving female protagonists, Booth, like Arora, identifies the contradictory assumption on which this genre lies: "In the hegemonic masculine view of the Hindi cinema, any woman would rather be respectably married to a man and dependent on him than be a tawaif" (ibid.: 14), a preference that is surely at odds with the very spirit of independence that makes this character distinctive.

Still, it is this pervasive incongruity in the courtesan film that interests me, and I am not the first to be intrigued by it. The entire last chapter of Sumita S. Chakravarty's National Identity in Indian Popular Cinema, 1947-1987, which dwells on the disruptive potential embedded in the courtesan figure, eloquently concludes by drawing a parallel between the instability that marks her narrative and that which underpins the entire Bombay industry:

The courtesan genre $\ldots$ is the limit-case of this cinema's ideological inconsistencies.... For a cinema that seeks to address the whole of Indian nationhood ... to take in the whole of Indian culture, both magnified and reduced to manageable entities and constructs, can hardly avoid the consequences of its own hubris. And so the critical space that the Bombay film opens up for itself through the aestheticization of the courtesan figure and the turning of this figure into a valorized cultural emblem must be at the cost of a repression .... she is a romanticized Other whose cultural contributions the dominant society has already acknowledged but whose sexuality remains outside its normative horizons. (Chakravarty 1993: 305)

I like this idea of hubris, implying as it does an excessive pride or confidence and even a strained reach beyond what is sensible, and if we are to read Hindi cinema as embedding a nationalist agenda, we need to turn to Indian nationalist history to determine where its reach has exceeded its grasp and what that grasp was seeking to contain or rein in.

It has long been argued by various scholars that mainstream nationalism, the kind that cinema tends to encode, sought to deliver India from British imperialism but without radically altering the nation's cultural, social, and political priorities. One of the tools it used to accomplish its mission was femininity, a strategy that was largely successful in that it blindsided the masculine machine that was the British Empire. But this strategy also resulted in the flooding of elite-class and upper-caste women into a public sphere to which they had in precolonial times only a highly restricted access. The problem then was how to rein these women back in and keep them from encroaching too far on a domain of life that Indian patriarchy had claimed especially for elite men, specifically the world outside the home, where profitable careers were to be had and political power could be wielded. The answer was the construction of a new normative kind of middle-class femininity that appeared to reward women by making them embodiments of the nation itself. And as the embodiments of the nation, their sexual behavior had to be policed and their emergent autonomy curtailed. This new middle-class femininity was above all a selfless one, which was maternally inspired, domesticated, and marked by its relentless heterosexual drive for marriage and children, or to put it another way, for a man and his offspring, especially his male offspring. 5 That Hindi cinema makes heterosexual marriage the only option for women, that it largely represents women as suffering to uphold familial relationships and family values, even to the point of sacrificing

5. This reading of nationalist history is now well known. Those looking for texts that present these theories and explore this history should see, for example, Tanika Sarkar's 1989 essay (Sarkar 1989), Ashis Nandy's 1990 book (Nandy 1990), Madhu Kishwar's two 1985 essays (Kishwar 1985a, 1985b), and Partha Chatterjee's 1989 essay (Chatterjee 1989), all of which are listed in the references section. 
themselves for the benefit of their husbands and their children, suggests just how informed this cinema is by this nationalist imperative.

But hubris conjures up its own nemesis as its inescapable fate. A reach that excessive, that encompassing, is bound to tremble, to let things slip out of its grasp, things which might inevitably work to bring about the downfall of its own hubristic embrace. The gender tensions that numerous scholars have noted in Hindi films can certainly be read as signs that this construction of womanhood cannot be sustained because it conflicts so frequently with the desires and aspirations of actual women: the actual women in the cinema hall or at home watching the film and the actual women in front of the camera performing these roles. I think that the courtesan figure is an especially efficacious nemesis for this particular nationalist ideology. For it is the fundamental incongruity at the heart of her narrative that can lead us to the great anxiety about women that Hindi film seeks to mask with its unceasing stories about heterosexual love, failed or fulfilled, and maternal sacrifice. It is precisely that which makes her so appealing as a character-her cultivated physical loveliness, her often heartbreakingly beautiful dance and music, and her enhanced sexual choice- that also ensures that she must either be harnessed to one man by the end of the story or be abandoned to loneliness or even made to die while trying to preserve the conventional family and society that has rejected her, all as if in punishment for being a courtesan. ${ }^{6}$ But film after film, from Mamta to Pakeezah to Amar Prem to Umrao Jaan to Tawaif to Utsav (directed by Girish Karnad in 1985), also presents the advantages of the courtesan's life in the form of the freedoms it makes possible: the freedom to create art and to pursue a living with it, for instance, and the freedom to behave and speak without having to consider the strictures of middle-class femininity. In fact, Hindi cinema's courtesans are far more compelling as characters before they are reformed by romantic love and made to want to be wed.

Sultana (Rati Agnihotri) in Tawaif, for example, is a feisty young woman when we first meet her, whose facial expressions suggest that men and their concerns bore her and whose body exhibits a charmingly careless abandon that is meant to be read as her resistance to middle-class ideals concerning female comportment. In one early scene, she sprawls

6. Both Mamta (directed by Asit Sen in 1966) and Adaalat (directed by Kalidas in 1958) end with a court scene in which the courtesan is redeemed by dying. relaxed on a chair, a cigarette in her hand, her head back, and her legs crossed. This free attitude is then abruptly contrasted with her constrained behavior and modest pose after the neighbors knock on the door. Then, when forced to pretend to be a wife, she finds ways to demonstrate her unwillingness to take the role seriously, mocking her pretend husband's fear at her physical proximity to him and mischievously teasing him. The film begins as a comedy with Sultana in control of most of the laughs. When it shifts its mode, dangling in front of us the tragic possibility of her entrapment in a way of life that no longer seems to represent freedom and excitement for her, we are obliged to watch her descent into pathos. Similarly, Chand (Mumtaz) in Khilona and Vasantsena (Rekha) in Utsav are extraordinarily self-possessed professional women before their heterosexual yearning for their men turns them into sobbing losers in the love game. Pakeezah and the 1981 Umrao Jaan are renowned for their nostalgic and lush imaginings of the nineteenth-century Lucknavi world of the kotha, a historical culture that these films clearly appreciate and the loss of which they mourn. Yet, finally, Pakeezah and Umrao Jaan cannot imagine this world as anything but a prison for their heroines. Obviously, the courtesan genre rests on a discrepancy between the narrative's moral teleology - which requires the courtesan to be rescued from the kotha and transformed into a wife or that insists that we should see her failure to escape as her tragedy — and the film's equally powerful expression of desire for her and her art. As a result, no matter how much the narrative tries to make us believe otherwise, these female characters seem diminished by their longing for a traditional marriage or family. So here then is the incongruity more boldly stated: a genre whose popularity is based on the appeal of the courtesan, the gorgeousness of her art, and the extraordinariness of her role within Indian society cannot also expect its audience to buy into the idea that such a life is not worth preserving and that this form of unconventional femininity is not valuable, even to the courtesans themselves.

But while it might be thought provoking to spot incongruities in cultural products such as film, merely identifying them cannot take us much farther than the surface of a text or of the sociocultural structure they help to create. It seems to me that their usefulness lies in the fact that they are beacons of sorts: their presence points to larger forces at work and helps us to decipher what is at stake, what is being protected by a superficial repetitive pattern, and what cannot be admitted or is 
unspeakable within the terms of the consciously known ideological parameters of any particular cultural or social formation. Given the ideological link between Hindi cinema and the mainstream nationalist project, a link that has been well-established by various scholars, given further the nationalist attack on all of the traditional female artistic professions that resulted in the suppression of these professions as well as the appropriation of their art by middle-class Indians in the name of the nation, ${ }^{7}$ and given even further the attempt by members of this same class to wipe away the connection between these female professionals and the musical and dance forms they created and nurtured, it only makes sense to unearth the courtesans' historical relationship to the Hindi film industry. What can be made apparent by such an unearthing are the psychological investments at stake in Bollywood's simultaneous obsession and contempt for the tawa' if. What is equally important is that when we connect the nationalist construction of the courtesan figure in Hindi film to the lived history and to the living women who continue to practice artistic traditions received through matrilineal lines, we are lending our support to activist projects that, in turn, can provide us with female models of resistance whose strategies and the knowledge gained by enacting them can invigorate our own theoretical understandings about power and how it might be subverted.

The last 20 or so years has seen the effort by scholars to recover the history of India's courtesans, including the devadasis from the south and east and the tawa' ifs of the north, an effort that has gradually gained more momentum since the turn of the twenty-first century. These scholars suggest that the courtesans functioned as a sort of historical hinge, which, in terms of the production of art, linked the colonial or feudal age to the modern one. Their significance, however, has been virtually erased by the ascendancy of a bourgeois nationalist class, which sought, sometimes consciously and deliberately, to cover up the courtesans pivotal role, installing itself and its members into the narrative of the nation as its heroes and heroines, or, in other words, as the ones who

7. For more extensive examinations of the historical appropriation of courtesan art forms, see Srividya Natarajan's 1997 dissertation (Natarajan 1997), Amrit Srinivasan's 1985 essay (Srinivasan 1985), both Qureshi's and Maciszewski's essays in The Courtesan's Arts (Quresh [2006] and Maciszewski [2006]), Whitmer's 2004 essay (Whitmer 2004), and my own 2010 essay (Hubel 2010) on the subject. rescued India's performing arts from their debasement by the process of Britain's colonization. But it was, in fact, the courtesans who kept alive many of the musical and dance traditions that are now celebrated as quintessentially Indian and that globally define India as a place especially rich in its performing arts. Such a definition has enormous economic ramifications, for there is a good deal of money to be made from being seen to be the legitimate purveyor of a performance tradition, and institutions as seemingly unattached as the film industry, the classical dance academy, and private musical tuition all depend on their ability to be able to stake just such a claim.

Scholars have pointed out that, unlike many of the princely houses, the profession of the tawa if managed to outlive the British campaign to dominate northern India, which entailed the occupation of various princely states and came to something of a climax with the annexation of the kingdom of Awadh in 1856. The exile of Nawab Wajid Ali Shah and his courtiers finally ended the feudal patronage that had sustained the tawa' if, but British authorities continued to besiege their artistic traditions and cultural practices, intending to fatally undermine a community that they believed was a key player in the resistance to imperialism staged by the 1857 Rebellion. While researching for her study on the transformation of Lucknow after the Rebellion, Veena Talwar Oldenburg (1995: 259) discovered evidence that the British confiscated much of the property of the Lucknavi courtesans, who through such actions were being "penalized for their instigation of and pecuniary assistance to the rebels." The British government sought even greater control over the profession through a series of Acts, including the Cantonment Act of 1864 and the Contagious Diseases Act of 1865, which made it official policy not only to relocate some of these kotha women to British cantonments, where they were made to sexually service the European soldiers, but to subject them to regular invasive medical checkups to verify their disease-free status. That these policies did indeed punish the courtesans is evident in the testimony of one of Oldenburg's sources, Gulbadan, who insisted that, in addition to offending "our dignity and sense of pride," this scheme of turning many of the courtesans into prostitutes for the Raj actually succeeded in increasing the incidence of venereal disease among them (Oldenburg 1984: 141).

But, though harassed by government regulation and the rule of law, the tawa ifs did not die out. Instead, they accommodated themselves to the new capitalism that was beginning to emerge in the later nineteenth 
century. Regula Burckhardt Qureshi (2006: 318) argues that the courtesan's kotha

enjoyed increasing prominence as the first venue for Hindustani art music that was accessible to the growing commercial and colonial elite cadres outside the control of princely hosts.... Salons proliferated in urban centers across northern India and Pakistan, and they continued to flourish in large numbers even during the years of World War II when war contractors generated an upsurge in patronage.

Yet, while the courtesans of northern India managed to survive the efforts of British imperialism to wipe them out, even achieving some kind of prosperity in the late nineteenth and early twentieth centuries, their profession could not finally thrive in the face of a nationalist reform movement that was determined to eradicate them. In an attempt to create and then normalize a new middle-class femininity and using British propaganda against the courtesans, social reformers condemned them for being a backward remnant of a dead feudal era and defined them as prostitutes whose presence was a blight on the nation. One of the last nails in the coffin was an edict issued by a newly independent government in 1954, which banished from the airwaves of All India Radio any female performer "whose private life is a public scandal" (quoted in Qureshi 2006: 312). As a consequence the tawa "if "as tawa "if" disappeared from the national cultural arena, leaving the way clear for men and women from the bourgeoisie to take over both their dance and their music.

However, some of them were able to parlay their skills and talent into careers in Hindi cinema, though often having to change their names in order to obscure their roots in the courtesan tradition. In "Moving beyond Themselves," Mrinal Pande traces some of the connections between early Hindi cinema and the tawa if families, and she documents their struggle to break into an industry that was initially so male-centric that it sought to save all the roles, even the female ones, for men. The eventual success of the tawa'ifs in establishing careers as actresses she ascribes to their history and experience as professional women:

[W] lomen like Gauhar and Fatima Begum ultimately owned [sic] their survival to the gustiness of the very matriarchal "tawaif" tradition they worked so hard to escape .... The matriarchal family backgrounds of all these women had taught them never to be taken for granted or taken for a ride, and to have their professional talents honed all the time. (Pande 2006: 1651)
Nargis, Madhubala, and Meena Kumari are examples of successful Hindi film stars from the 1940s, 1950s, and 1960s who either hailed from tawa' if families or learned tava' if arts. Their contribution to this cinema is, I think, especially evident in the distinctively non-Western style of dance performances that we see more substantially in many films produced before 1990. A comparison of Madhubala's dance in Mughale-Azam (directed by K. Asif in 1960), Meena Kumari's in Pakeezah, or Rekha's in Umrao Jaan, for instance, with that of most contemporary Bollywood film-star dancers demonstrates just how far film dance has fallen away from the classical proficiency sustained by India's courtesans and by their male teachers, such as Lachchu Maharaj-who was the choreographer for the two earlier films and whose artistic heritage flows back to the same Nawabi culture as Lucknow's famous courtesansand those teachers' female students, including Kumudini Lakhia, the choreographer of the 1981 Umrao Jaan and student of Lachchu's brother Shambhu. ${ }^{8}$ While Madhubala's abhinaya (the art of expression) shows at least an attention to detail that only a dancer attuned to the subtleties of the tawa'if's dance can achieve and Meena Kumari and Rekha are quite striking and convincing as traditional dancers, most of the female actors since the 1990s liberalization of the economy can often be graceful, but the facial expressions and dance steps they are given to perform are usually much less difficult, rigorous, or precise and tend to include many more Western-style movements, such as grinding and other modified moves from hip-hop. The steps in some recent Bollywood films even look a little like those used in aerobics, which are clearly meant to be learned after only one or two tries. Fewer and fewer of the classical gestures and dance steps remain in current Bollywood dance as the historical links between the courtesans and Hindi cinema get thinner and actors and actresses from middle-class backgrounds begin to dominate the screen.

8. In her chapter in the Encyclopaedia of Hindi Cinema, Lata Khubchandani (2003: 203) establishes both Meena Kumari and Rekha as receivers of dance forms traceable to the historical court of Wajid Ali Shah, which is often represented as the epitome of Nawabi culture, because she connects these film stars to the famous Maharaj brothers: Meena Kumari directly, since she performed Lachchu's dances, and Rekha through Shambu Maharaj's student, Kumudini Lakhia. Significantly, Shambu Maharaj, the brother of Lachchu, describes himself in Ashish Mohan Khokar's online column on dance as the teacher not only of students from middle-class and upper caste families but also of tawa ifs (see Khokar [2008]). 
Today in India the courtesans are far from gone entirely. Various feminist researchers have documented their continuing struggle to preserve their legacies, though their scholarship does seem to suggest ambivalent realities for the inheritors of the tawa' if profession. Oldenburg describes them as a vibrant community of skilled women whose lives constitute a conscious rejection of patriarchal authority. Her fiercely argued justification of their choices and practices culminates in a rousing acknowledgment of the difference they represent: "it is ... in the kotha, rather than in the 'normal' world, that female sexuality has the chance of being more fairly and fearlessly constructed by women" (Oldenburg 1995: 283). Amelia Maciszewski (2006: 333) offers a darker image of their postcolonial realities:

Except for the outstanding few who have been accepted as mainstream artists, tawa' if lead a precarious existence, living in poverty- and crime-ridden red-light districts where the present-day clientele is more interested in sex than songs, and the songs "patrons" wish to hear often have little, if anything, to do with the rich traditions these women embody.

Yet, in addition to being a testament to the extraordinary musical endowment of these singers and their daughters, her essay ends on a hopeful note in its recognition of the cultural integrity of these professionals who must negotiate with well-meaning though often patronizing middle-class advocates and a mainstream media that seems unable to conceive of them as much beyond "fallen women."

9. Trisha Gupta draws attention to the continuing subjugation of working-class and/o lower-caste performing women by a middle-class morality that seems unaware of its own hypocrisy. Describing the 2005 ban on Mumbai's bar dancers, which, she claims, threw 75,000 women out of work, Gupta (2009) states that this attack is "eerily similar to the Anti-Nautch campaigns of a century ago" since, like the tawa 'ifs and devadasis, many of these women are hereditary professional performers from tribes like the Deredar, Nat, Bedia, and Kanjar. Her article ends with the following astute observation:

In early 20th century India, it was dance that seemed to lie at the root of moral opprobrium. The tawaif gave up the mujra to acquire respectability as a concert singer or actress. But in a newly-globalised India where "Bollywood dance" is now a legitimitised "cool" activity for the urban middle classes - think NRI/urban weddings, Shiamak Davar classes, TV shows like Boogie Woogie and Nach Baliye, feeding back into films like Dilli-6 or Rab Ne Bana Di Jodi-how does dance reacquire its immoral connotations when performed by women in bars? (Gupta 2009)
The Hindi film industry is, of course, a facet of this mainstream, so its similar vision of the courtesan as invariably degraded has a profound influence on how these women can be depicted in any other media. But this depiction is an interested one that disguises itself as a universally held morality. Considering that, to use Qureshi's (2006: 325) words, the "kotha was in fact the first public concert venue of broad attraction," that the tawa 'if's music and her dance remain foundations of the Hindi masala film, and that many of the earlier actresses who helped to popularize this industry were raised in tawa' if families and/or trained in tawa ' if arts, it seems perfectly reasonable to surmise that this cinema itself is one of the social, artistic, and cultural legacies of the courtesan profession. In short, Bollywood is a descendent of the kotha. Even more significantly, it is the courtesan's art that marks popular Indian cinema as different from any other global cinema. Bollywood film bears the traces of its origins in its obsession with the courtesan heroine, the courtesan story, and the courtesan's art. Its insistence on the almost exclusive reiteration of that narrative for the purposes of extolling the virtues of the wife would seem to point to a deeply embedded apprehension about not only the stability of wifehood but also the ramifications of the tawa' if's sexuality. In the powerfully patriarchal world that the Hindi cinematic narrative repetitively portrays and implicitly promotes, the courtesan functions as a fetish. And the disavowal that fetishes psychologically mandate, in this case, a disavowal of her history and her link to the film industry itself, nevertheless leaves behind traces that can be retrieved, piece by piece, in the development of an analysis that can lead us back to the courtesan's central, though repressed role as the choice that wives and wives-to-be must not be permitted even to imagine, much less make.

Fareed Kazmi argues that, while many courtesan films appear to offer especially female audiences an image of powerful and defiant womanhood, such a connotation is

a sham, a ruse to trap any genuine rebellion against gender inequality ... the narrative neutralizes, absorbs and displaces any potential for subversive action and, instead, projects a totally different concept of woman as malleable, ready to fit into the graded, hierarchical social system and thereby reinforce the inequitable gender relations which they seem to be attacking. (1994: 233)

On their glittering surfaces, these films certainly do disseminate a retrogressive ideal for girls and women. But this kind of reading relies 
on an understanding of the Hindi cinema as essentially realist in its thrust and hence mimetic in its effect, turning films into mirrors of sorts that work to reflect the tensions that exist in Indian culture. Realist aesthetics imply a seamlessness between a visual image and the object it purports to represent. Feminist film theory, however, can demonstrate the illusion of this seamlessness and render visible the gap between the image and its purported referent. By separating the signifier, the visual image, from the signified, the thing in the so-called real world to which the image claims to point, feminist aesthetics can reveal, to use Laura Mulvey's words, "a mobility and instability of meaning," which can be deployed as a "source of liberation" (1993: 3). Rather than conceiving this genre of Hindi cinema as a realist disseminator of a conservative, patriarchal imperative, we might instead understand its glittering surface as a symptom that points the way to those forces that Indian patriarchy is always struggling to keep in check but that ultimately remain outside of its control. Or as Mulvey states, "The image refers, but not necessarily to its iconic referent" (ibid.: 3). The tawa 'if in Hindi cinema is a fantasy figure or a phantasmagoric site that marks the place where the historical tawa'if, with all her fearsome meaning, has been suppressed. Far from representing "real" women, Bollywood's fetishized tawa if is a symptom in a process of patriarchal disavowal that is seeking to rewrite history so as to singularize female choices.

In psychoanalytical theory, disavowal is a mechanism of the unconscious that works to displace from consciousness something that is traumatizing and threatens the ability of an individual ego to maintain its fabricated sense of wholeness or coherence. Fetishism is a symptom or a sign that such a displacement has occurred. Displacement is not the same as the more complete operation of repression, for displacement allows traces of the trauma to remain in the form of the fetish. Freud insists that disavowals are "half-measures, incomplete attempts at detachment from reality. The disavowal is always supplemented by an acknowledgement: two contrary and independent attitudes always arise..." (quoted in Mulvey [1993: 6]).

For psychoanalytical film theorists, mass culture takes the place of the individual ego in Freud's work, for it functions as "a massive screen on which collective fantasy, anxiety, fear, and their effects can be projected. In this sense, it speaks to the blind spots of a culture and finds forms that make manifest socially traumatic material through distortion, defense, and disguise" (Mulvey 1993: 6). Emerging as it does from a process of disavowal, the fetish, which is always culturally specific and usually visually excessive, works to conceal the fact that a blind spot even exists by creating the appearance of a plenitude or wholeness or truth and so rendering unnecessary any exploration of the blind spot. Fundamentally, then, the Freudian fetish involves "the setting up of a sign, which is of value only to its worshippers, to conceal a lack, to function as a substitute for something perceived as missing ..." (ibid.: 8).

It is my argument that the courtesan in Hindi film operates as a fetish in that this figure stands in as a substitute for the historical and contemporary tawa if, whose history and reality is largely missing from Indian mass culture, having been displaced by the demands of a middleclass nationalist movement that required a new monolithic model of womanhood-the heterosexual and middle-class wife. For this new model to function as an emblem of the nation, all other competing expressions of Indian womanhood - the tawa'if and other courtesans of India included - had to be suppressed and the history of the nation had to be rewritten to ensure that these older expressions were so seriously delegitimized that they could, in effect, be forgotten. That the tawa' if was not forgotten, but instead lingers glimmeringly in the reiteration of the visually excessive courtesan figure in film after film, attests to the "problem in reference" (Mulvey 1993:7) that she represents. The courtesan figure is a defense against the courtesan herself, against her disruptive potential as an alternative to the normative femininity that Bollywood cinema tries to make her proclaim. She is the fetish that conceals the lack of female choice. As an image, she is a substitute for that choice. But her insufficiency as a substitute for that choice is evident in the sham, the ruse that Kazmi identifies in the courtesan genre: it only seems to advocate a rebellion against inequitable gender relations, but ultimately it fails to lead its female audience anywhere but back to a wifely, patriarchal femininity.

But, as Mulvey expressively asserts, "[t] he fetish ... is always haunted by the fragility of the mechanisms that sustain it" (1993: 7). While the courtesan film does not generally advocate rebellion, it does point the way toward it. As a fetish, the courtesan heroine is an object of desire for male and female, homosexual and heterosexual spectators. In her glittering and extravagant display of a femininity so sexualized as to be her defining characteristic, the courtesan is made to embody an exotic femininity for Indian audiences, the exotic being an amalgam of the 
hyper-erotic and the sinful or taboo. This construction of an exotic and hence profoundly desirable femininity represents the acknowledgment always implicit in a fetish, in this case an acknowledgment of its origin in the historical and contemporary courtesan herself, specifically in her capacity for both sexual and professional choice. In other words, the courtesan figure points to the actual courtesans, who stand as evidence that wifehood in not inevitable, that the availability and control of women through the institution of marriage is neither natural nor even a sensible option for girls and women, for whom marriage can, and often does, bring about a deprivation of freedom and a diminishment of sexual and professional choice. ${ }^{10}$

Furthermore, this genre countenances a reversal in gendered behavior: it is the female courtesans who, rather than exhibiting the passive submissiveness generally required of Hindi film heroines, are the active and energetic heroes of their films, while the men they love frequently display an inability to act decisively or a general helplessness or weakness in the face of social disapproval. The narrative's trajectory towards tragedy is often dependent on their refusal to defy tradition and set up house with the courtesan they claim to adore. " So Sultan Sahab (Farooq Shaikh) in

10. The tendency in Hindi cinema to depict the courtesan as having few choices is belied by the biographies of actual historical courtesans, many of whom had a substantial range of possibilities available to them. As David Courtney (1998) writes:

The tawaifs had options open to them that were generally denied women of a more domestic nature. If they had professional aspirations, especially in the artistic fields. they had a virtual monopoly. If they desired to settle down, marriage was always an option. From what we know of history, when this option was taken it was often with only the wealthiest and most well placed men. Remember their mastery of etiquette and the social graces made the tawaifs a "prize catch," for almost any man. If they desired an independent lifestyle, this too was an option which the tawaif could exercise that was denied most women of the period. This is born out by an examination of tax rolls that tend to show only tawaifs as female property owners and tax payers. The tawaifs were often poets and authors, in a period when the majority of women were illiterate. When everything was considered, the tawaifs had education, independence, money, power, and self-determination, in a period when many women were little more than cattle.

While this was true of some tawa'iff, though not all, I think the point he makes is a relevant one because it demonstrates just how blinkered and limited Hindi filmmakers continue to be in their recreations of courtesans' lives.

11. I am indebted to Booth's (2007) essay for this insight. the 1981 Umrao Jaan does not defy his mother or father and marry the tawa' if he loves, choosing instead to marry the woman his mother has trained and handpicked for him, and Anand (Rajesh Khanna) in Amar Prem, though charming in his drunken soulfulness, leaves the courtesan (Sharmila Tagore) to rescue herself. Through such characterizations of both men and women, tawa if films reveal that gender itself is a construct, constituted out of reiterated performances rather than biological necessity or some other inherent inclination, a revelation which is surely dangerous to hegemonic gender categories, since it raises the distinct possibility that, given a real choice, with no negative consequences, Indian girls and women might eschew marriage, monogamy, and maybe even heterosexuality itself in favor of the adventure that masculinity or courtesan-hood seems to promise.

Yet it is not solely Indian girls and women and Indian boys and men who are watching Hindi films. Bollywood is now and perhaps has always been a globalized industry that reaches across nations and continents in its promotion of nationalist messages. But although these messages might be the surface intent of many Bollywood films, their reception cannot be guaranteed because so many of the assumptions on which these films rely are psychologically and politically specific. To put it plainly, you have to be Indian to get these encoded messages on any truly efficacious level; you have to be Indian for them to work in your world, to actually affect its contours. Fetishes, for instance, are among those elements of film that are not culturally transferable. I reiterate Mulvey's (1993: 8) words again: the fetish is "a sign, which is of value only to its worshippers." In terms of the films that make up the courtesan genre, the question becomes, then, what happens when non-Indians view them, or when the viewers are Indian but are able to resist the pull of middle-class normativity by virtue of their placement in the working or even subaltern classes?

While I am not in a position to speculate on what the courtesan might mean when she is seen from the perspective of non-normative Indian cultures and classes, as a white Canadian viewer of Hindi film, I can certainly testify to the appeal of the courtesan figure, whose sexual and visual abundance is as mesmerizing for me as she seems to be for so many Indian viewers. But not being a product of a history that required the suppression of the tawa if and the devadasi, nor having access to the cultural barrage that locates normal femininity so assiduously in marriage, I can only partly read or imbibe the message that the courtesan as fetish conveys. Her sexual transgression is less of an issue for someone 
whose mainstream culture of morality does not demand absolute sexual monogamy in women. In fact, for me and viewers like me, the array of the courtesan's sexual choices is relatively commonplace. So there is no ingrained way for me to code the tawa'if as taboo. And because she cannot touch such unconscious depths, the courtesan figure cannot carry the psychological weight of the fetish. Far from being a fetish, she can instead serve as a model for the Canadian viewer, particularly the female viewer.

I had this theory confirmed for me when I showed the 1981 Umrao Jaan in an Indian literature and film course to a class of mostly white Canadian upper-year female undergraduate students. In a discussion after the film, the students were almost universal in their admiration for this film's heroine. One student wrote:

The inner artist and natural poet within Umrao Jaan was appealing to me. She had a natural talent which separated her from the other women and gave her power. ... Her ability to express herself through poetry shows that she didn't passively accept her fate but could intelligently face and articulate her deep emotional conflicts. (Salvas 2009)

Her marketed sexuality only became an issue when I made it one, at which point one of the students observed that she could be compared to female actors in the Hollywood film industry; like them, her sexuality was one of the means of her success, but, in a patriarchal society that punishes women for consciously using their sexuality, she was made to pay the consequences for knowingly wielding it. Reading her story as a sad one, the students, with few exceptions, still saw her position as an artist as enviable. I suspect that what makes the courtesan figure so attractive to especially female western spectators is the relationship between her accomplished and confident sexuality and the artistic tradition for which she is a vehicle. Mainstream Canadian female viewers have also been taught to understand themselves as sexual beings, but not how to harness the power of sexual desire for the production of art.

As with Indian audiences, the courtesan's attraction for Canadian viewers like me and my students does partake of the exotic, if what we mean by exotic is a "mixture of the sinful and the sensuously beautiful" (Marglin 1985: 5). A legacy of European imperialism, the exotic is a negative category within postcolonial theory. It is, therefore, thought to be both a demeaning and debilitating designation for women. But can the exotic be a route to social justice?
I think it can. If "soft power" is "attractive power" (Nye 2004: 6), as Joseph Nye declares in his 2004 book, there are few things more attractive to a Western audience that has been primed by its centuriesold fascination with Eastern femininity than the Indian courtesan figure, which reaches global audiences primarily through the exportation of the subtitled DVD. Nye also notes, however, that, though governments can exercise hard power in a relatively straightforward way, soft power "is more difficult to wield, because .... many of its crucial resources are outside the control of governments ..." (ibid.: 99). India's government might these days be celebrating Bollywood as a form of soft power that can be made to work in the interests of the Indian state, as Anjali Gera Roy points out in the introduction to this book, but perhaps government ministers such as Shashi Tharoor and Manmohan Singh are overestimating their ability to manage how Bollywood images and narratives are interpreted outside of India's borders. Surely courtesans, with their links to older, pre-nationalist states and systems of value, might actually work against a nationalism that, like most contemporary nationalisms the world over, proclaims the normality of middle-class morality and middle-class ambitions.

As I have suggested, how non-intended audiences might read the courtesan image is not entirely predictable, though some of the terms of its reception can be foreseen by its embeddedness within the European category of the desirable exotic. Postcolonial theory typically reads colonial desire mostly as masculine and heterosexual. ${ }^{12}$ But this desire also works between women in much the same way that patriarchy trains every one of us, men and women, to be attracted to the feminine. For heterosexual men, this attraction leads to a desire to sexually possess the exotic. For heterosexual women, given their roles as objects of hegemonic masculine gaze, this attraction is more likely to produce a longing to be like the exotic. Hence, the exotic can work as a model of behavior for certain of those viewers who are not bound by its fetishistic imperatives. And just as the courtesan figure as fetish, though a substitute for the historical and actual courtesans, is also intimately tied to them, so too the courtesan figure as model rather than fetish can lead the outsider searching for more knowledge of her historical and contemporary reality as well as her art to those real-life women whose lives gave rise to her. For the Western feminist, the courtesans of India possess a further special significance,

12. See, for example, Robert Young's Colonial Desire (Young 2002). 
since their traditions, values, and practices represent examples of working matrifocal and matrilineal communities, and the Western world today is largely lacking in these.

In her essay on a group of North Indian tawa' ifs who in the last decade or so are beginning to find new venues for their art in the Guria festivals, which seek to preserve performance traditions that are endangered in modern India, Amelia Maciszewski (2006: 353) describes these women as "adapting to changing musical patronage in the twenty-first century, using their music and dance as a tool for empowerment." Bollywood's courtesan can lead us to these live women. Our role, it seems to me, is to transform our colonial desire into postcolonial support for them.

\section{REFERENCES}

Arora, Poonam. 1995, "Sancrioned and proscribed narratives in Indian cinema: A bicultural reading of the courtesan film." In Kostas Myrsiades and Jerry McGuire (eds), Order and Partialities: Theory, Pedagogy, and the "Postcolonial" (pp. 59-85). Albany, NY: State University of New York Press.

Bhaskar, Ira and Richard Allen. 2009. Islamicate Cultures of Bombay Cinema. New Delhi: Tulika.

Booth, Gregory D. 2007. "Making a woman from a tawaif: Courtesans as heroes in Hindi cinema." New Zealand Journal of Asian Studies 9 (2, December): 1-26.

Chakravarty, Sumita S. 1993. National Identity in Indian Popular Cinema, 1947-1987. Austin, TX: University of Texas Press.

Chatterjee, Partha. 1989. "The nationalist resolution to the women's question." In Kunkum Sangari and Sudesh Vaid (eds), Recasting Women: Essays in Colonial History (pp. 233-253). New Deihi: Kali for Women.

Courtney, David. 1998. "The tawaif, the anti-nautch movement, and the development of North Indian classical music, Part 2-The tawaifs." Chandra and David's homepage. http:// chandrakantha.com/articies/tawaif/ (accessed on February 19, 2010).

Gupta, Trisha. 2009. "Bring on the dancing girls." Tehelka Magazine, 6 (44, November 7). http://www.tehelka.com/story_main43.asp?filename=hub071109bring_on.asp (accessed on February 19, 2010).

Hubel, Teresa. 2010. "The high cost of dancing: When the Indian women's movement went after the devadasis." In Davesh Soneji (ed.), Bharatanatyam: A Reader (pp. 160-184). Delhi: Oxford University Press.

Kazmi, Fareed. 1994. "Muslim socials and the female protagonist: Seeing a dominant discourse at work." In Zoya Hasan (ed.), Forging Identities: Gender, Communities and the state in India (pp. 226-243). Boulder, CO: Westview.

Khokar, Ashish Mohan. 2008. "Kathak Samraat Shambhu Maharaj. The dance history column." Narthaki: Your Gateway to the World of Indian Dance. November 4. http://www.narthaki. com/info/tdhe/tdhc2.html (accessed on February 18, 2010).

Kishwar, Madhu. 1985a. "Gandhi on women. Parts I and II." Economic and Political Weekly 20 (40, October 5): 1691-1702.
Kishwar, Madhu. 1985b. "Gandhi on women. Part III." Economic and Political Weekly 20 (41, October 12): 1753-1758.

Khubchandani, Lata. 2003. "Song picturization and choreography." In Gulzar, Govind Nihalani, and Saibal Chatterjee (eds), Encyclopaedia of Hindi Cinema (pp. 197-208). New Delhi and Mumbai: Encyclopaedia Britannica (India). Google Books. http://books.google.ca/books id=8y8vN9A14nkC\&pg=PT221\&lpg=PT221\&dq=Song+Picturization+and+Choreogr aphy+Encyclopedia + Britannica+India\&source $=$ bl\&cots $=r w R v-f C o j 5 \&$ sig $=\mathrm{Bp} 93 \mathrm{uFY} 9 \mathrm{~d} 7 \mathrm{w}$ gK7bngH IPgh2xkYY\&hl=hi\&sa=X\&ci=9XkcT5DUDOjc0QGdrMSVCw\&ved=0CBg Q6AEwAA\#v=onepage\&q\& $\mathrm{f}=$ false (accessed on February 19, 2010).

Maciszewski, Amelia. 2006. "Tawa' if, tourism, and tales: The problematics of twenty-firstcentury musical patronage for North India's courtesans." In Martha Feldman and Bonnie Gordon (eds), The Courtesan's Arts: Cross-cultural Perspectives (pp. 332-351). Oxford: Oxford University Press.

Marglin, Frédérique Apffel. 1985. Wives of the God King: The Rituals of the Devadasis of Puri. Delhi: Oxford University Press.

Mulvey, Laura. 1993. "Some thoughts on theories of fetishism in the context of contemporary culture." October 65 (Summer): 3-20.

Nandy, Ashis. 1990. The Intimate Enemy: Loss and Recovery of Self under Colonialism. New Delhi: Oxford University Press.

Natarajan, Srividya. 1997. "Another stage in the life of the nation: Sadir, bharatanatyam, feminist theory." PhD Dissertation, University of Hyderabad, Hyderabad, India.

Nye, Joseph S. 2004. Soft Power: The Means to Success in World Politics. New York: Public Affairs.

Oldenburg, Veena Talwar. 1984. The Making of Colonial Lucknow, 1856-1877. Princeton, NJ: Princeton University Press.

1995. "Lifestyle as resistance: The case of the courtesans of Lucknow, India." In Ngaire Naffine (ed.), Gender, Crime and Feminism (pp. 259-287). Aldershor, UK: Dartmourh.

Pande, Mrinal. 2006. “'Moving beyond themselves': Women in Hindustani Parsi theatre and early Hindi films." Economic and Political Weekly 41 (17, April 29): 1646-1654.

Qureshi, Regula Burckhardt. 2006. "Female agency and patrilineal constraints: Situating courtesans in twentieth-century India." In Martha Feldman and Bonnie Gordon (eds), The Courtesan's Arts: Cross-cultural Perspectives (pp. 312-331). Oxford: Oxford University Press.

Salvas, Victoria. 2009. "Questionnaire from English 2363F." Huron University College, Ontario, Canada. November

Sarkar, Tanika. 1989. "Politics and women in Bengal-the conditions and meaning of participation." In J. Krishnamurty (ed.), Women in Colonial India: Essays on Survival, Work and the State (pp. 231-241). Delhi: Oxford University Press.

Srinivasan, Amrit. 1985. "Reform and revival: The devadasi and her dance." Economic and Political Weekly, 20 (44, November 2): 1869-1876.

Whitmer, Olivia. 2004. "Dancing the past into the present: Ruth St. Denis and Bharatanatyam." Journal of Popular Culture 37 (3, January): 497-504.

Young, Robert J. C. 2002. Colonial Desire: Hybridity in Theory, Culture and Race. London and New York: Routledge. 
Copyright Agreement: All material, excluding any third party material, included in the PDF is the exclusive property of SAGE Publications, or its licensors, and is protected by copyright and other intellectual property laws. The download of the Work is intended for the User's personal and non-commercial use. Any other use of the download of the Work is strictly prohibited. User may not modify, publish, transmit, participate in the transfer or sale of, reproduce, create derivative works (including course packs) from, distribute, perform, display, or in any way exploit any of the content of the Work in whole or in part. Permission may be sought for further use from SAGE Publications Ltd, Rights \& Permissions Department, B-1/I-1, Mohan Co-operative Industrial Area, Mathura Road, New Delhi 110 044. By downloading the Work, the User acknowledges and agrees to these terms.

Title: "From Tawa'if to Wife? Making Sense of the Bollywood Courtesan Genre" Author: Teresa Hubel, PhD

Originally appeared as Chapter 12 in The Magic of Bollywood: At Home and Abroad

Editor: Anjali Gera Roy

(C) SAGE Publications Pvt. Ltd., 2012 